\title{
Meten is ... meer weten
}

\section{Peter Leeflang}

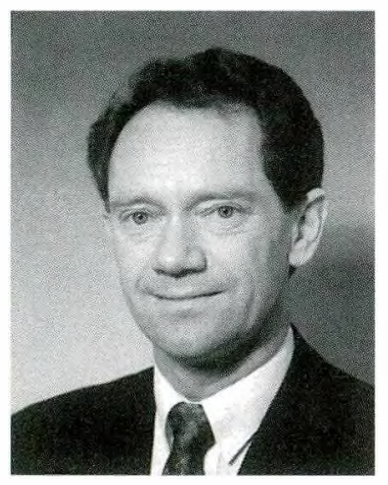

In de loop van het

2

3

\lrcorner
0
$u$

afgelopen jaar zijn er nogal wat opmerkelijke beslissingen genomen. In Amsterdam n'erd besloten een nieuw' stadion en een nieuwe grasmat (!) in gebruik te nemen. In Rotterdam werd de Erasmusbiug geopend en daarna weer gesloten. Het kabinet nam (veelal tegen de zin van de kamer in) besluiten over de HSL, accijnsverhogingen voor shag, sigaretten, pijptabak en benzine. Men besloot om niet langer door te gaan met Sport 7 en in veel, heel reel ondernemingen werden budgetheslissingen genomen.

Wat mij steeds meer opvalt is dat het lijkt alsof steeds meer decision-makers spreken in termen van: "wij denken, wij geloven, wij menen, wij vorroelen...', 'naar alle waarschijnlijkheid zal ...'. 'als ik om mij heen kijk' en 'ik denk dat ik op basis ran deze steekproef van weliswar $n=1, \ldots$.

Steeds meer managers schijnen vanduag de dag ook dingen aan hun 'water' te voelen. Dit staat in schril contrast tot een uitspraak waarmee ik zelf hen grootgebracht en die luidt: 'meten is ... weten'. Ik 'weet' intussen dat deze

Prof. Dr. P.S.H. Leeflang is als hoogleraar Marktkunde en Marktonderzoek verbonden aan de Faculteit der Economische Wetenschappen (FEW) van de Rijksuniversiteit Groningen. uitspraak niet houdbaar is; dat heb ik geneten. Maar er ligt nog heel veel tussen al dat geloven. menen, volen enerzijds en 'zeker weten door meten', anderzijds.

De kw'aliteit van de grasmat van de Arena werd pas gemeten toen er direct serieus op gespeeld moest worden. De tuien van de Erasnushrug, zo heb ik hegrepen, waren niet voldoende getoetst op een combinatie van windkracht en regen. Zou men daar niet aan gedacht hebben of zou men dat niet voorveld hebben ... .

It heb dagenlang geprobeerd om er achter te komen waarop de hoogte van de accijnsierhogingen ran rookartikelen, die tot de ontmoediging van de tabakconsumptie zouden moeten leiden, is gehaseerd. Talloze telefoontjes naar het Ministerie van Economische Zaken leiden er in ieder geval niet toe dat er een studie boven water kont waarin prijselasticiteiten roor tabaksproducten bepaald zijn. Waarop is overigens het besluit gebaseerd dat het verbod op de verkoop van tabaksproducten aan jongeren onder de 18 jaar tot ontmoediging en daling ran het a antal nieuw'e rokers leidt? En waarom moest er zonodig een accijnsverhoging voor pijptabak konien: is dat ook om jongeren te ontmoedigen? Deze markt daalt 'vanzelf' al met zo' n 5 tot $10 \%$ per jaar. Nog erger wordt het als ik hoor wat tal ran 'specialisten' beweren over het vermeende effect van reclame op de consumptie van rookwaren. Zonder dat het waagniveau (totale vraag naar rookwaren/totale vraag naar sigaretten/ vraag naar een merk) gespecificeerd wordt, stelt men dat tabaksreclame effect heeft en dus verboden moet worden.' 
Voor de accijnsverhogingen van benzine kan waarschijnlijk hetzelfde geconcludeerd worden. Omdat ook hier geen rapport boven water kan worden gekregen zal het hedrag dat bepaald werd om het autogebruik te ontmoedigen waarschijnlijk wel op basis van -'denk ik'- hegrotingsoverwegingen bepaald zijn.

In juni 1996 werd onder leiding ran mijn collega Dr. K.J. Alsem een onderzoek gehouden naar de marktkansen van Sport 7. ${ }^{2}$ Uit dit onderzoek bleek dat de kijkdichtheid zeer sterk bepaald werd door het al dan niet betalen, van een overigens gering bedrag, voor deze zender. Als er niet betaald zou hoeven te worden zou Sport 7 zo'n $f 70$ miljoen aan reclame-inkomsten kumnen genereren. Zou men w'el voor het kijken naar deze zender moeten betalen dan zouden de kijkdichtheden en navenant de reclame-inkomsten sterk dalen. Toen mijn collega Alsem aanhood om dit onderzock voor $f 75$,- ter beschikking te stellen aan de directie ran Sport 7 en om dit onderzoek toe te lichten werd dit hautain van de hand gev'ezen. Men 'voelde' zelf wel aan wat de markt voor mogelijkheden bood ... en men 'schatte' dat de reclame-inkomisten wellicht wel meer dan het dubbele zouden zijn. Overigens wist Sport 7 in de maanden van haar. bestaan toch zo'n $f 13$ miljoen aan reclameinkomsten binnen te halen. Op jaarbasis en met wat verbeteringen zegt 'mijn gevoel' dat ....

Natuurlijk zijn er ook heel goede beslissers en komen er heel veel beslissingen gefundeerd tot stand. Alhoewel, ... het kan natuurlijk stukken beter. Enkele voorheelden. Wij geven in Nederland aan reclame voor merkproducten en diensten jaarlijks zo'n $f 4$ miljard uit. Aan marktonderzoek dat ten grondslag zou moeten liggen aan deze bestedingen wordt evenwel maar zo'n $f 15$ miljoen uitgegeven. Het gevolg is dat veel reclamegelden verspild worden. Men legt zich daar heel raak bij neer, omdat een reclamegoeroe in het verleden eens gezegd schijnt te hebben dat de helft van alle reclame verspilling is, maar dat je niet weet w'elke helft dat is. Wij weten evenwel dat wanneer reclame in staat is om een bepaalde doelgroep te bereiken en dit geen effect op de consumptie van een bepaald merk heeft. het geen zin heeft om dit budget te verhogen. Wij weten ook dat dan een herallocatie over andere media, een andere campagne. een andere timing meer effecten kan hebben.' Wij w'eten dat, maar wij gebruiken dat niet. Waarom? Omdat wij te weinig vertrouw'en hebben in meten, meer vertrouwen op onze intuitie of omdat het in onze situatie nu net een beetje anders is.

lets dergelijks kunnen we opmerken met betrekking tot het geld dat we uitgeven aan promoties (prijskortingen, spaarzegels, gratis n'eggevers, prijsvragen). Per jaar wordt er in Nederland zo' $n$ f 6 tot 7 miljard uitgegeven aan zogenaamde landelijke promoties. Omdat dit bedrag niet wordt gemeten, weet ik dit bedrag niet exact. Wel weet ik dat er naast deze landelijke promoties, 'tailor made' promoties zijn die in samenw'erking tussen een fabrikant en één detailhandelsorganisatie specifiek voor deze laatste organisatie en haar klanten ontwikkeld worden. Van de landelijke promoties is zo'n $8 \%$ gericht op de handel (handelspromoties). De andere promoties zijn de consumentenpromoties. gericht op finale consumenten, zoals "en ik.

Uit Amerikaans onderzoek weten we dat slechts $16 \%$ van de handelspromoties en $11 \%$ van de consumentenpromoties winstgevend $z i j n .{ }^{+}$ Dit is niet verwonderlijk omdat volgens (alweer) een schatting ${ }^{5}$, normaliter slechts $1 \%$ van alle promoties op hun specifieke effect worden geëvalueerd. We weten dat dit zo is, maar we meren niet waar en waarom dit gebeurt!

Ik zou de bovenstaande voorbeelden op diverse manieren kunnen aamullen. Wat ik met deze voorbeelden zeggen wil. is dat we bij het nemen van beslissingen onvoldoende gebruik maken van gegevens en aan deze gegevens ontleende informatie. Moeten we dan al de intuitie, het buikgevoel, het 'water' over hoord zetten? Ik denk dat dit ook niet juist zou zijn. In een brochure van het gerenommeerde marktonderzoeksbureau A.C. Nielsen", die ik onlangs onder ogen kreeg, staat het zo mooi geformuleerd: 'Wij geloven in intuitie. Die staat vaak aan de basis van succes....

Intuitie.... is nodig om beslissingen snel te kumnen nemen, als ze snel genomen moeten w'orden. Maar intuitie hoort gebaseerd te zijn op kennis. Hoe meer kennis u hebt, des te beter zal uw ondernemers- of marketinginstinct werken'... Met 'meten' krijgt 'het w'eten', meer basis, meer voeding. 
Kunnen w'e dan alles meten en kunnen w'e onze metingen vertrouwen? I $k$ denk dat deze wragen voorlopig nog ontkennend beantwoord moeten worden. Wel zal de ontwikkeling van de informatietechnologie de relatie tussen meten en w'eten steeds sterker doen w'orden. Daarnaast zullen we onszelf, onze studenten. onze juniors moeten blijven trainen in meten en het veden van onze intuittie met meetresultaten. Vakken als 'algemeen en bedrijfseconomisch onderzoek', methodologie, marktonderzoek, methoden en technieken zullen daarom naar mijn mening aan inhoud en belangstelling moeten winnen, willen we in de toekomst onze beslissingen een beter fundament geven. Niet omdat meten per definitie weten is maar omdat we met meten in ieder geval meer kunnen weten.

\section{N O T E N}

1 Bijv. De Poorter en Van Muijen in het Algemeen Dagblad van 6 september 1996 en de uitspraken van kamerleden die zij in dit verband citeren. We zullen deze wat ruwe uitspraken gezien het karakter van het $M A B$ hier niet herhalen en verwijzen naar deze publicatie.

2 Rapport 'Sport 7 Winnen of Verliezen' Rijksuniversiteit Groningen, Faculteit der Economische Wetenschappen, Sectie Marktkunde en Marktonderzoek.

3 Zie bijv. Lodish, L.M. et al., (1995), 'How T.V. Advertising Works: A Meta-Analysis of 389 Real World Split Cable T.V. Advertising Experiments', Journal of Marketing Research, vol. 32, pp. $125-139$.

4 Zie Abraham, M.M. en L.M. Lodish, (1989), 'Fact-Based Strategies for Managing Advertising and Promotion Dollars: Lessons from Single Source Data', working paper \# 89.006. Marketing Department, the Wharton School of University of Pennsylvania.

5 Persoonlijke informatie van $\mathrm{H}$. Stegenga, Coopers \& Lybrand, Management Consultants, Utrecht.

6 A.C. Nielsen (Nederland) 'Wij weten wat de kraker wordt'. 